\title{
MUSIKANG BAYAN (PEOPLE'S MUSIC) AND THE MILITANT-MATERIALIST- PROGRESSIVE-NATIONALIST MUSIC ${ }^{1}$
}

\author{
Noe M. Santillan \\ University of the Philippines-Cebu, Philippines
}

\begin{abstract}
Music is a cultural Ideological State Apparatus (Althusser 1971, 143 148). In such a lens, this paper proceeds in the manner of Althusser's argument, and the critique applies to popular music in the Philippines vis-à-vis Gramsci's cultural hegemony. With such a framework, this paper looks into the albums of Musikang Bayan (People's Music) from 2001 to 2019 and employs qualitative content analysis. In doing so, the themes are dealt with vis-à-vis the Philippine socio-politico-economic condition. The country's socio-cultural atmosphere in the mainstream music industry is "not so" critical since social institutions are part of the relations of class domination (Althusser 2014, xxiv). Only if music is oriented with the people's struggle will it become scientific and carry forward emancipatory politics transforming society. Musikang Bayan encapsulates the militant-materialist-progressive-nationalist music against the 'fetish-character' of today's neoliberal capitalist ideology; hence, it articulates the collective consciousness through music.
\end{abstract}

Keywords: base-superstructure, cultural Ideological State Apparatus, Althusser, cultural hegemony, Gramsci

\section{INTRODUCTION}

Music is always part of human affairs. Its themes vary from love, violence, sex, politics, etc. But more often than not, it does not mirror the material condition of society. As such raises concerns on contradictions and alienation (Althusser 2005, 200206). Filipino musicians had performed abroad as early as the Commonwealth Period (Ang 2018, 28). Music is always part of the Philippine society's socio-cultural activities. From Valentine's Day to the Christmas Season, music dominates the people's cultural consciousness reverberating from houses, churches, schools, offices, public and private vehicles, business, and political propaganda. However, today's capitalist ideology, particularly mainstream Philippine music, is dominated by popular themes unconnected with the country's socio-politico-economic conditions; this is evident in the daily top ten and/or the hit chart whether on TV and radio. Such a 
phenomenon indicates a trend in performing rather than producing music, e.g., music competition is looking for more singing talent than to the ability to compose. Notwithstanding this fixation, there is as well another problem between performing and recording artists as such reflects the admonition of Althusser $(2015,58,88,97$, 116) on fetishism. In a ranking of the top ten Filipino singers and bands, the environmental and socio-political term appears only once in the descriptions of the artists' work (Vila, 2018). Nonetheless, many of these progressive artists and their music are quite unpopular today, especially to the country's major population, i.e., the youth $^{2}$. If popular songs are becoming unpopular, those that are militant-materialistprogressive-nationalist (MMPN) are unfamiliar. With the aforementioned context, this paper claims that today's popular music in the Philippines is divorced from society's material condition. More often than not, pop music does not deal with the political, economic, and/or intellectual. It opiates using an idealist perspective rather than citing the concrete condition through a materialist lens. As a matter of fact, the progressive music of nationalist musicians has lesser views and "likes" on YouTube than those considered pop.

It has been established that music plays a vital role in revolutionary movements. The American Civil Rights Movement employed freedom songs sung at protests and rallies (Cronenberg 2008, 9). Around the world across centuries, protest songs are playing a significant role in people's struggles: the Bolsheviks and the anthem "L'Internationale," the American Revolution and "Yankee Doodle," the French Revolution and "La Marseillaise," the Young Turk Revolution of 1908 and the "Mshag Panvor [Farmer, Laborer]," Ireland's Easter Rising of 1916 and "The Foggy Dew," the Mexican Revolution and the "La Cucaracha," the Cuban Revolution and the "Hasta Siempre," the Cultural Revolution and "The East is Red," and the Romanian Revolution of 1848 and the "Deșteaptă-te, române! [Wake Up, Romanian!]" (Gilmore 2017).

Despite these historical accounts of employing music in people's struggles, popular songs dominate in the Philippines over the militant ${ }^{3}$ progressive,${ }^{4}$ nationalist,${ }^{5}$ scientific, ${ }^{6}$ materialist, ${ }^{7}$ and mass-oriented. ${ }^{8}$ Commodification characterizes popular music giving more weight to entertainment than to the prophetic role (Elicor 2016, 7996). In this regard, music becomes an "alienated product" unable to contribute to rewriting history (Althusser 2005, 226). In the Philippines, music is struggling to keep its prophetic purpose with the exception of a few artists. Hence, this paper wrestles with the hegemonic power of the capitalist ideology and recognizes the relationship between music and the material condition as a carrier of a "renaissance" in culture towards "economic emancipation" and "political independence" from foreign influence (see Constantino's Miseducation). So, what is the role of popular music? What type of culture does it promote? How should it function? Does it elicit a critical analysis of society? Or does it give opiate to the people disorienting them with an absurd idealist theme? Does it take active participation in the people's struggle? Does it construct a clear and critical analysis of the socio-politico-economic issues? Is it written out of the hopes, struggles, and lived experiences of the people at the lower strata of the social structure? These are the questions this paper would like to shed light. In doing so, this paper may contribute to the country's discourse on the 
philosophy of art by positing music as cultural Ideological State Apparatus (ISA), which, if properly directed, can articulate the collective consciousness of the people from their material condition.

\section{MUSIC: CULTURAL IDEOLOGICAL STATE APPARATUS}

Ideas and beliefs are embedded in social institutions, inseparable from economic activity (Powell, Smith, \& D'Amore 2017, 1-3). They are neither apolitical nor neutral as they seem since, according to Althusser $(1971,170)$, "there is no practice except by and in an ideology; there is no ideology except by the subject and for subjects." In order to renew the mode of production, the state needs consciousness that the citizens have to embody, so they legitimize, support, and maintain the "established order" that the capitalist ideology may not be thwarted. And this is possible through cultural ISA overseeing the molding of the citizens' social mind. Moreover, music is observable in how it avoids the socio-politico-economic condition (Horsley 2015, 63 cited in Powell, Smith, \& D'Amore 2017, 1). Such avoidance is nothing but a cautious and fearful act not to disturb the base-superstructure dynamics. Otherwise, the repressive ISA, e.g., military, police, prison and/or court, imposes itself as the state's muscle repressing what it considers detrimental to the "established order." Recently in the Philippines, repression, threat, and intimidation abound coercing a popular song, ${ }^{9}$ a national TV series, ${ }^{10}$ visual art, ${ }^{11}$ and even journalism, e.g., imprisoning Lady Ann Salem of Manila Today. As to why Althusser explains the bearing with base-superstructure dynamics.

... social formation which did not reproduce the conditions of production at the same time as it produced would not last a year (Marx cited in Althusser 1971, 127)... the reproduction of labor-power requires not only a reproduction of its skills, but also... a reproduction of its submission to the rules of the established order... for the domination of the ruling class... (Althusser 1971, 132-133).

Althusser (1971, 134-135) clarifies the dynamics by dissecting society into infrastructure, i.e., the base and superstructure. The former refers to the "economic base," i.e., the society's mode of production or the economic activity, and the latter to the law and the state and its ideologies, e.g., religious, ethical, political, educational, cultural, etc. And these social institutions "ensure subjection to the ruling ideology," Althusser (1971, 133) argued, and accordingly, there is "reciprocal action of the superstructure on the base" (Althusser 1971, 135-136). Music, as part of the cultural ISA, is not spared, and in the process, it becomes alienated from the society's material condition and the people's struggle. Though deliberating ISA is subtle and sensitive, recent repressions against a rapper and progressive artists reveal the fangs of the state. Elicor (2016, 83-88) explains by elucidating the relationship between "music and the consumer society." Such is the relationship between music, society, and the state. Guerrero $(1970,33)$ calls this scenario a "superimposition of ... ideology ... within the superstructure." In order to root its influence, capitalist ideology employs cultural hegemony. The cultural ISA may not be noticeable as the repressive like the police 
and the military or other ISAs, e.g., the Church, schools, media, courts, prisons, etc., but according to Althusser $(1971,146)$, "no class can hold state power over a long period without at the same time exercising its hegemony over and in the State Ideological Apparatuses." Thus, the state works covertly, but sometimes blatant, despaired by its intention to produce docile and submissive citizenry supporting, legitimizing, and maintaining the "established order." Revealing the state's covert hold to ISAs is like determining the "invisible hand" of the self-and/or class interest (Levy $2011,1-5)$. Althusser $(1971,144)$ divulges that even those that claim private are also social, political, and/or economic.

...there is a plurality of ideological state apparatuses. Even presupposing that it exists, the unity that constitutes this plurality of ISA as a body is not immediately visible... It is unimportant whether the institutions in which they are realized are 'public' or 'private.' What matters is how they function. Private institutions can perfectly well 'function' as an Ideological State Apparatus.

In this case, it does not excuse the neoliberal framework. Music, as cultural ISA, works in other apparatuses, e.g., politics, education, religion, family, media, etc. In the Philippines, religion and media, which also function like education, can serve as a tool for the people maximizing songs that are MMPN. One good song to note is the composition of Levy Abad, Jr. with the band Musikang Bayan. Titled Awit ng IFI [Song of the Iglesia Filipina Independiente], the song tells about the church as the Church of the poor, the exploited, the oppressed, and the marginalized, but collectively struggling: "ito ang ating Simbahan iniluwal ng Inang Bayan sa panahon ng pagkaalipin sa panahon ng pagbabalikwas" [This is our Church borne by our Mother Country during the time of enslavement and uprising]. However, instead of employing such an approach, common religious songs are so celestial that people tend to forget what's going on with the parish and its parishioners. Consequently, churchgoers are aiming for the afterlife while at the same time ignoring the concrete condition of the people. The year 2018 had observed the (in)efficiency of the Catholic Bishops Conference of the Philippines' Pastoral Guidelines for Discerning the Moral Dimension of the Present-day Moves for Charter Change. ${ }^{12}$ Amid homilies, fora, and processions, there is no evident decisive discernment among the Filipino Catholics. The Church can make the most of the influence and efficiency of music. Danny Fabella (2019), the lead-vocal composer of Musikang Bayan, elucidates the relationship of the Church with the society's material condition. In his Pro Deo Et Patria [For God and the Country], he sings "ang mabuting salita ay magiging masama kung hindi isasabuhay sa tuwid at tama; sa ating pagsisilbi sa dukha't inaapi, pangalan niya'y ating pinupuri" [Good words become bad if they're not put into just deeds; we praise God's name in serving the poor and the oppressed]. History shapes and conditions the Church, and the people can shape history differently according to their culture and mindset (Labayen 1995, 52-54). The laity may have been conscienticized $^{13}$ if religious songs are progressive enough to remind the people of their roles in social transformation as worded by Pope Paul VI in his encyclical Populorum Progressio 
(n.13) quoting Gaudium et Spes: "since the Church lives in history, she ought to scrutinize the signs of the times and interpret them in the light of the Gospel" (n. 4, sec. 1). In doing so, the prophetic tradition carries on in an untraditional yet convenient, effective, and efficient manner, e.g., conscientization through music. Bishop Labayen $(1995,58)$ exhorts "to evangelize cultures... to promote an alternative culture to the predominant cultures of the times and, in doing so, to reshape history." Culture plays an important role in the historical process (Mao, Gramsci, Gen. Douglas MacArthur, and Pope Paul VI cited in Labayen 1995, 71-72). The "cultural renaissance"14 and/or cultural revolution, then, must not only precede but also accompany the social transformation even after the success of the people's struggle ${ }^{15}$. Making the cultural ISA relevant, Althusser $(1971,154,155)$ elucidated the role of social institutions.

The communications apparatus by cramming every 'citizen' with daily doses of nationalism, chauvinism, liberalism, moralism, etc., by means of the press, the radio, and television. The same goes for the cultural apparatus... The religious apparatus in sermons and the other great ceremonies of Birth, Marriage, and Death, that man is only ashes, unless he loves his neighbor to the extent of turning the other cheek to whoever strikes first...

Each mass ejected (from school) en route is practically provided with an ideology which suits the role it has to fulfill in class society: the role of the exploited (with a 'highly-developed' 'professional', 'ethical', 'civic', 'national' and 'a-political consciousness')...

Social institutions identified with superstructures "ensure subjection to the ruling ideology" (Althusser 1971, 133). To this extent, different professions have an indispensable part in the people's struggle. Instead of subservience to state apparatuses and hegemonic power, a new type of culture should be MMPN. National Artist for Film Eric Oteyza de Guia, popularly known as Kidlat Tahimik, shares the aforementioned character of culture. "Resist cultural imperialism!", Kidlat reiterates Constantino's "cultural renaissance" in a plenary talk during the national conference themed Society, Heritage, and Indigenous Arts organized by the Philippine National Philosophical Research Society (PNPRS) in February 2019 at Saint Louis University in Baguio City ${ }^{16}$.

Struggles precede social transformation, and national consciousness is necessary for countering neoliberal aggression in globalization (Amin 2014, 10-11). There is difficulty in promoting MMPN music amid neoliberal aggression. However, ideology is manufactured and is determined by class struggles (Althusser 1971, 160), and struggle has many faces, both armed and none-armed, violent and nonviolent, educational, religious, political, cultural, etc. Althusser $(1971,161)$ defines ideology as a "representation of the imaginary relationship of individuals to their real conditions of existence." Today's popular songs operate with unscientific culture exploiting and wasting the dynamism of the youth by not arousing the consciousness in failing to portray the society's material condition critically. This is recognizable in most gigs/concerts in the country, which last throughout the wee hours of the morning but 
the message of the performance is vain as far as the social issues are concerned; the hit charts and/or the daily top ten provide constant proof. While companies may profess to promote progressive perspective through music, it is but a lip service (Elicor 2016, 89-90).

There is, therefore, a cause for the imaginary transposition of the real conditions of existence: that cause is the existence of a small number of men who base their domination and exploitation of the 'people' on a falsified representation of the world which they have imagined in order to enslave other minds by dominating their imaginations. (Althusser 1971, 163)

If music does not reflect the genuine material condition of people's lived experiences, it may alienate them from their concrete condition. In other words, there's no "lived relation" and expression between the people and their world (Althusser 2005, 233-234). The cultural ISA portrays the relations to the material condition (Althusser 1971, 164). Consequently, people are kept in line since ideology implies material practice in material ceremonies and rituals through social activities overseen by both public and private institutions (Althusser 1971, 169-170). Moreover, the role and function of ISA like culture through music can be described in its intended effect: “... an absolute guarantee that everything really is so, and that on condition that the subjects recognize what they are and behave accordingly, everything will be all right..." (Althusser 1971, 181). Capitalist ideology in this manner breeds docility and submission unless class struggle is embedded in countercultural activity, say in music, whose message sticks to the subconscious until it functions covertly to replace the old with a new ideology.

The ideology of the ruling class does not become by the grace of God, nor even by virtue of seizure of State power alone. It is by the installation of the ISAs in which this ideology is realized and realizes itself that it becomes the ruling ideology. But this installation is not achieved all by itself; on the contrary, it is the stake in a very bitter and continuous class struggle: first against the former ruling classes and their positions in the old and new ISAs, then against the exploited class. (Althusser 1971, 185)

Music and class struggles bear ideology since ideologies are not borne independently of class. "The artist is nothing more than a worker for the greater, and... the collective good", said Mogos $(2016,24)$ since culture is an agent towards a new social order (Giles and Kuhn 2015, 231). Social transformation requires what Paulo Freire calls conscientization in his Pedagogy of the Oppressed, and with what activists are doing, i.e., arousing the consciousness before organizing and mobilizing. Amado Guerrero $(1970,137)$ reiterates the same concept in his Philippine Society and Revolution and calls it "awakening" through "cultural activities". Since the society's transformation comes with conscientization, cultural artists do it by filling in their work with themes that are MMPN. However, as to why mainstream media prefer playing 
popular music over the progressive, Jenny Justice (2019) explains that mainstream media and the powerful do not want a conscienticized citizenry. In this regard, Guerrero $(1970,137)$ suggests an infusion of "traditional and modern cultural forms." Such a suggestion bears a resemblance to what Kidlat Tahimik talks about in his plenary talk at PNPRS 2019 national conference, i.e., "adjust foreign ideas and inject our own." In this manner, critical cultural artists can efficiently amplify countercultural hegemony towards "cultural renaissance." National liberation comes with cultural work, but the country needs not just progressive artists but also militant. As part of the ISA, the media suppresses music that is MMPN since portraying the society's material condition in such a manner shakes the "established order." It shakes the foundation of the power of the few. This does not mean to say no to foreign cultures but an adaptation of "progressive foreign culture" to meet the "national conditions" (Guerrero 1970, 137).

The purpose of such a scientific culture is "to oppose the reactionary idealism... and superstitions... be expressive of the heroic struggles and aspirations of the toiling masses...", said Guerrero $(1970,137)$. This culture is rooted "from the experience of the masses" and filled with "a higher ideological content" (Guerrero 1970, 138). How about at school? Can we hope to promote critical thinking vis-à-vis "cultural renaissance" in music? Jenny Justice (2019) elucidates how structures are set in the school system to appropriate consumerist character. Consequently, in most Philippine schools, one can hear Western if not Korean pop music more often than those that are MMPN. People can barely listen to music with lyrics telling what is happening in their society. At this point, this paper will continue to deliberate by maintaining the importance of articulating collective consciousness, so culture is transformed that politics becomes emancipatory through the very own hands of the people despite the hegemonic power of the ISAs.

\section{ARTICULATING COLLECTIVE CONSCIOUSNESS THROUGH MUSIC}

"There is a need to strengthen unity and set the militant spirit ablaze," said former Department of Social Welfare and Development (DSWD) Secretary, Prof. Judy Taguiwalo (2019), in her review of Danny Fabella's recent album Kung Kami'y Manlalaban [If We Are To Fight Back]. In terms of a broad alliance, the participation of the people from the society's basic sector is very important (Labayen 1995, 56). In times of socio-politico-economic and/or moral crisis, civil disobedience is, according to Habermas $(1985,99)$, "an element of a mature political culture." In this regard, it is significant to promote MMPN music and amplify the society's material condition.

The mobilization of organized individuals is impossible without arousing their consciousness. Althusser (2006, 21-23), in favoring Lenin over Kautsky, cites the significance of consciousness of those in the mass movement. If formal education fails to conscienticize, MMPN music may fill in the void. In a way, the materialist narrative can counter the idealists'. Idealist music does not serve the material welfare of the people; it is beneficial to the hegemons' interests. Hegemony has to be countered by "cultural renaissance." As Glassman $(2013,242)$ had put it, "hegemony is a concept which shows that political maneuvering matters and leads to historically contingent 
outcomes." Thus, in exploiting, oppressing, and marginalizing the people, hegemony breeds revolution (Gramsci cited in Glassman 2013, 243). Evading social unrest and/or revolution, the state adopts the theory that "coercion... has to be ingeniously combined with persuasion and consent" (Gramsci cited in Glassman 2013, 243). In order to keep people in line, consciousness becomes a political arena. Althusser (2006, 26-27), in tracking the early works between Marx and Engels on political economy, emphasizes not just political consciousness but political class-consciousness.

Meanwhile, Glassman expounds the concept of hegemony from Joel Wainwright's On Gramsci's Conceptions of the World (2013): “hegemony... is not a narrowly 'cultural' project of implanting ideas in the mind but a broader social project - inclusive of cultural dimensions..." Since consent has to be manufactured, coercion is combined with persuasion but humans, no matter how hegemonized, always have the capacity for intellectual activity (Glassman 2013, 244). Fearing for the activation of the intellect, the cultural ISAs are paired with the repressive ISAs, e.g., the military, police, prison, and court, and historical materialist analysis is inherent in Gramsci's critique of unjust treatment of neo-colonies by capitalist countries (Short 2013, 211). Glassman $(2013,245)$ did posit the (in)security of the "established order" and that "hegemony...is also tenuous and contestable because it is always established on the terrain of uneven development and may be eroded by the ongoing dynamics of development and class struggle." Glassman considers the connection between conscienticizing and transforming society. Althusser $(2006,56)$ argues that "social existence determines consciousness," and the "transformative behavior" sprouts from contradictions towards restructuring the social world (David Harvey cited in Glassman 2013, 247).

While the people may not be able to read on their own, MMPN songs can continuously awaken their consciousness. To this end, MMPN artists, e.g., Musikang Bayan, challenge and undermine the financial success that bourgeois idealist music offers. "A sad but true and fulfilling reality," says Danny Fabella (2019). However, artists like Danny Fabella choose to perform so they can portray society's material condition. MMPN artists want to transform the themes of popular music in the Philippines, not the genre. They do adapt with the evolution of genres catering to the demand of listeners without sacrificing the content. MMPN music is indeed employed among different genres, including those palatable to the 'fetish-character,' but the mainstream music has only one theme among different genres, i.e., bourgeois idealist, - a claim Danny Fabella (2019) shares. "In different human experiences, i.e., joy, sadness, love, hate, etc., the theme is more or less the same among different artists who come and go with time," Fabella (2019) explains. Pursuing MMPN music may not have financial success, but the sowing of critical consciousness through songs composed out of the society's material condition will eventually agitate and conscienticize the listeners. Listeners may not reach the third level of Freire's Pedagogy, i.e., act on the material problem, but at least they will have a clearer and more critical understanding of society. However, instead of articulating people's consciousness, popular music opiates the people's cognizance. In as much as hegemony influences, MMPN songs can counter the idealist dilution of the people's culture. Adam David Morton $(2013,50-51)$ explains how state power dominates 
"relations in civil society including culture." Morton did so by citing the role of Gramsci's argument on having critical consciousness before "contesting state power." However, people's participation in social struggle is more likely to happen if they are conscienticized to transform the political society by rooting social consciousness to the material culture (Fontana 2013, 126-127). It is not correct to say that one's existence is ahistorical. Fontana claims $(2013,127-128)$ that "human action is always historical; humanity...is acting in nature, it becomes the maker and creator of its history." Thus, humanity is both the creator and the creature, the subject, and the object, of history. The poet, singer-songwriter Jess Santiago (2019) describes Danny Fabella in the former's review of the latter's recent album Kung Kami'y Manlalaban.

Poetic keeper of history. Sharp scrutinizer of social issues. Strong, courageous, and creative artist of society... Hear the rhythm and the beating of his music, feel the sincerity of his voice, and see the truthfulness of his words. True, it is time to cast "the spell of darkness" and see again the "light of the morning".

Music as an integral part of human activity historicizes the human subject. It should not only entertain but should also conscienticize. It is a process that corrects false consciousness making it scientific. It is through activities like singing, especially community singing, that consciousness is articulated. And to acquire new consciousness is infrequent even though music is ubiquitous from the toilet to the prayer meeting. Acquiring new and critical consciousness develops new hegemony to establish a new order (Fontana 2013, 129-130). National Artist for Literature Bienvenido Lumbera (2019), in his review on the album Kung Kami'y Manlalaban, elucidates Danny Fabella's MMPN music vis-à-vis the aim for national liberation.

The music and the resounding lyrics of Danny Fabella are a very important and influential contribution to the militant mobilizations of mass-organizations. The vitality and depth of the issues scrutinized are fruits of the lived experience of social issues and the hope of foreseen freedom by the singer's voice. Danny's music has an intense effect on activists familiar with his work. In the history of cultural movement, the impact of its melody and lyrics is unforgettable, for it raises the spirit of mobilizations supported by Danny and his colleague-musicians. The activists who go through the art and politics of Danny's songs will render in the coming victory of the national democratic movement.

Emancipating the enslaved is feasible through the crafting of critical consciousness towards liberation by the scientific abstraction of the material condition (Rousseau, Hegel, and Marx cited in Fontana 2013, 137-138). However, without the "organic intellectuals", the new order may not be realized. According to Kipfer and Hart $(2013,335)$, "Gramsci is thus both vital and insufficient to approach anti and postcolonial nationalisms." For Gramsci, "organic intellectuals" are organizers (Kipfer and Hart 2013, 333), but there are few "organic intellectuals" at the grassroots. However, 
since the instruction during educational discussions and/or public fora can be remembered easily with MMPN songs, listening to such strengthens the consciousness. Thus, the "intelligent reflection" on the material condition is not monopolized by the intellectuals, contrary to the claim by Kautsky, which Althusser argued against. The praxis-theory dynamic relationship is still an effective guide, especially at the society's basic sector (Wainwright 2013, 171), and this praxis-theory relationship can be apprehended with MMPN music.

\section{MUSIKANG BAYAN AND THE MATERIAL CONDITION}

Bourgeois artistry is business-oriented, taking advantage of the unconscienticized. The market determines the fate of the artists. In this regard, there is a challenge to change the commodified culture since both the musician and the listeners fall into the fetishization of music. "It should have been the society giving life to music, not the capital," Fabella (2019) reiterates. Instead of music helping with people's education, it becomes a tool of the capital; it is not apolitical. Musicians may participate with the people's National Democratic Movement through MMPN songs. Danny Fabella (2019) explains.

The discussion of Mao Tse-tung at the Yenan Forum provides a lens to compose materialist music. Artistry in the mainstream falls under the category of bourgeois morality. Mao, at the Yenan Forum, raises the standards of arts vis-à-vis the society's material condition. Maximize the available popular form of art to amplify the message pursuing change the people hope for. In a capitalist society, it is not surprising that mainstream artistry produces nothing new, for such artistry serves the interests of the capitalists perpetuating themselves in power and, consequently, benefit from the consumerist character of music. Instead of conscienticizing the unenlightened, mainstream artistry, wittingly and/or unwittingly taking advantage of the popular taste despite the country's pressing problems, and this is evident in recycling love songs by different artists through different genres but with the same content - opiating. The artist's creativity should have a direction on how to transform society since artistry serves social transformation. While one may be fond of popular artists but admiration for artistry has different levels, e.g., biological (voice), technical (skills), and the highest level is that which concerns the artist's ideological lens and/or political line vis-à-vis the mass movement.

However, the bulk of artists comes from the petty-bourgeois whose consciousness is susceptible to becoming individualistic through technology transforming music from its collective character to being individualistic which doubles the susceptibility of music to becoming a commodity.

Music as part of community living, like teaching, can never be equated with money, but in a capitalist society, music, like teaching, is a commodity resulting in teachers and musicians alike chasing money after 
the nobility of music and teaching - a victim of the capital where the ruling class benefits from the bourgeois art. Music serves society, not the capital, but this is not the case in a neoliberal capitalist society.

With the western demonization of Mao through the ISAs, it is seemingly hard to teach about Mao's scientific and mass-oriented culture. One may do so, but once people will find out that it is Mao's idea, they may express disbelief. Nonetheless, many agree with resisting cultural imperialism through a culture that is nationalist, scientific, and mass-oriented. Yet many are also fooling themselves just to live, drink, and be happy, for tomorrow's material condition is still the same. As a philosophy of history, it is the cyclical school of thought, as such is relevant to "anachronistic entertainment" (Althusser 2005, 131). Death is the only thing certain for them, not the making of history by human effort. Hence, the capitalist ideology drowns the sociopolitico-economic dimension of MMPN music. However, the petty-bourgeois, whose stratum produces artists, can be the beacon of "cultural renaissance." In breaking through dogmatism, empiricism, bourgeois-political tendency, and remolding to proletarian consciousness, the petty-bourgeois is a reliable ally of the exploited class (Guerrero 1970, 7, 117). It is through the people's collective struggle that creates the highest form of music, but if the artist is not conscienticized, the artistry will eventually propagate bourgeois morality and will become an instrument of the state (Fabella, 2019). Fabella (2019), in Ang Dami ng Likes [Greater Number of Facebook Likes] of the album Walang-Hanggan [Eternal], emphasizes praxis, "aanhin ang dami ng likes kung walang na-organize, aanhin ang dami ng likes kung walang na-mobilize” [The number of 'Likes' earned from Facebook posts is useless if one does not organize and mobilize the masses]. Artists carry social responsibility. They and their listeners are "creators of culture," and culture helps in recreating history. "Confront culturally the culture of domination," said Paulo Freire, for "we have a system which achieves neither true knowledge nor true culture" (2000, 54, 80). Freire's explanation bears resemblance with Gramsci's cultural hegemony, "cultural conquest leads to the cultural inauthenticity of those who are invaded; they begin to respond to the values, the standards, and the goals of the invaders" $(2000,153)$. Break the "culture of silence," i.e., the colonial culture, through a music that is MMPN. As argued earlier, music has to be rooted in its people's time, and place for praxis is the criterion of truth. Perhaps, the people do not have the choice to prefer progressive over popular music. Nobody wants falsehood, but the problem is that nobody realizes that the known truth is untrue. As to the "technologically mediated" truth, a general resolution was written on May 42001 at Brussels during the International Communist Seminar titled Imperialist Globalization and the World Revolutionary Process. The resolution reaffirms the Althusserian argument concerning the few privileged and powerful mechanizing ISA.

In the hands of the monopoly bourgeoisie, information technology is a tool for mass deception, exploitation, and oppression. But in the hands of the revolutionary forces and people, it is a means for knowing social needs and demands, for promoting democracy, for effective planning, for 
attuning production to the general and specific needs of the people, for raising efficiency in production and distribution, and for developing revolutionary education and culture.

The bourgeois ${ }^{17}$ control of technology today is threatened by the rise of alternative media and the use of makeshift studios in recording without sacrificing the noble goal of communicating the concrete condition through the lens of an MMPN framework. At this juncture, after deliberating Gramsci and Althusser, this paper conducts a content analysis of Musikang Bayan's six albums from 2001 to 2019 visà-vis the country's socio-politico-economic problems.

\begin{tabular}{|c|c|c|c|}
\hline Album & $\begin{array}{l}\text { Sample } \\
\text { Song }\end{array}$ & Theme & Sample Lyrics \\
\hline $\begin{array}{l}\text { Rosas } \\
\text { ng Digma }\end{array}$ & $\begin{array}{l}\text { Rosas } \\
\text { ng Digma } \\
\text { [A Rose } \\
\text { In the } \\
\text { Garden of } \\
\text { War] }\end{array}$ & $\begin{array}{l}\text { Love, } \\
\text { Society, } \\
\text { Struggle, } \\
\text { and } \\
\text { Revolution }\end{array}$ & $\begin{array}{l}\text { Sumibol sa isang panahong marahas; } \\
\text { Bawat pagsubok ay iyong hinarap; At } \\
\text { hangga't laya'y di pa nakakamtan; } \\
\text { Buhay mo'y laging laan. [Sprouted } \\
\text { from a violent time; You faced every } \\
\text { trial; And as long as there's no } \\
\text { freedom; } \\
\text { You are ready to sacrifice your life] }\end{array}$ \\
\hline $\begin{array}{l}\text { Walang- } \\
\text { Hanggan } \\
\text { (Eternal) }\end{array}$ & $\begin{array}{l}\text { Pro Deo } \\
\text { et Patria } \\
\text { [For God } \\
\text { and the } \\
\text { Country] }\end{array}$ & $\begin{array}{l}\text { The } \\
\text { Church } \\
\text { and the } \\
\text { People's } \\
\text { Struggles }\end{array}$ & $\begin{array}{l}\text { Ang pagsamba sa Diyos ay may } \\
\text { kabuluhan, kung pag-ibig ay lubos sa } \\
\text { kapwa at sa bayan; ito ang sukatan ng } \\
\text { wastong paniniwala at buhay na } \\
\text { pananampalataya. } \\
\text { [There's meaning in worshipping God, } \\
\text { only if one's love is absolute for the } \\
\text { country and the people; this is the } \\
\text { weight of true faith and relevant } \\
\text { religious zeal] }\end{array}$ \\
\hline $\begin{array}{l}\text { Baliktad } \\
\mathrm{Na} \\
\text { Ang } \\
\text { Mundo }\end{array}$ & $\begin{array}{l}\text { Baliktad Na } \\
\text { Ang Mundo } \\
\text { [The World } \\
\text { Is Topsy- } \\
\text { turvy] }\end{array}$ & $\begin{array}{l}\text { Economic } \\
\text { Crisis } \\
\text { and } \\
\text { Social } \\
\text { Justice }\end{array}$ & $\begin{array}{l}\text { Ekonomya ay sumusulong; Ang } \\
\text { mamamaya'y nagugutom; Ang krisis } \\
\text { ay sagana; Ang glorya'y pagdurusa. } \\
\text { [The economy progresses; The } \\
\text { citizenry goes hungry. A crisis is an } \\
\text { abundance; Glory (Gloria Macapagal } \\
\text { Arroyo) causes suffering] }\end{array}$ \\
\hline Ilusyon & $\begin{array}{l}\text { Ilusyon } \\
\text { [Illusion] }\end{array}$ & $\begin{array}{l}\text { Foreign } \\
\text { Influence, } \\
\text { Land } \\
\text { Monopoly } \\
\text { and Elite } \\
\text { Politics } \\
\end{array}$ & $\begin{array}{l}\text { Hangga't pare-pareho mukhang } \\
\text { nakapaligid, mga asendero, } \\
\text { negosyanteng ganid, pulitikong bulok, } \\
\text { dayong mapanghimasok, ilusyon lang } \\
\text { ang pagbabago [So long as there are } \\
\text { traditional politicians, landlords, }\end{array}$ \\
\hline
\end{tabular}




\begin{tabular}{|l|l|l|l|}
\hline & & & $\begin{array}{l}\text { greedy capitalists, foreign influence, } \\
\text { change is just an illusion] }\end{array}$ \\
\hline $\begin{array}{l}\text { Igpaw } \\
\text { [to leap } \\
\text { over or } \\
\text { overcome } \\
\text { an } \\
\text { obstacle] }\end{array}$ & $\begin{array}{l}\text { Igpaw } \\
\text { Mindanao }\end{array}$ & $\begin{array}{l}\text { Struggles } \\
\text { for Land, } \\
\text { Life, and } \\
\text { Freedom }\end{array}$ & $\begin{array}{l}\text { Upang bigyang daan dambuhang } \\
\text { minahan na s'yang kumakamkam sa } \\
\text { likas na yaman sa lupang ninuno, } \\
\text { lupang katutubo, sa lupang pangako. } \\
\text { [To make way for monstrous mines } \\
\text { who grab nature's wealth from } \\
\text { ancestral lands, from our native land, } \\
\text { from the promised land] }\end{array}$ \\
\hline $\begin{array}{l}\text { Kung } \\
\text { Mami'y } \\
\mathrm{n}\end{array}$ & $\begin{array}{l}\text { Kung } \\
\text { Kamilaba } \\
\text { Manlalaban } \\
\text { [If We Are } \\
\text { To Fight } \\
\text { Back] }\end{array}$ & $\begin{array}{l}\text { EJK, War } \\
\text { on Drugs, } \\
\text { and }\end{array}$ & $\begin{array}{l}\text { Rumang kami'y manlalaban, di kami } \\
\text { Rights } \\
\text { Violations } \\
\text { habang kayo'y pumuputok at sabihing } \\
\text { kasi nanlaban. } \\
\text { [If we are to fight back, we would not } \\
\text { turn our backs with our hands up while } \\
\text { you fire your guns and claim that we } \\
\text { fought back] }\end{array}$ \\
\hline
\end{tabular}

Musikang Bayan captures not just the country's material condition but also the thesis of Althusser in his ISA. In Mga Asong Ulol [Mad Dogs], Musikang Bayan materializes and sings what Althusser philosophized: "silang nagbabantay ng trono, sinanay ng dayong sundalo upang lalong manatili ang amo nila sa paghahari; mga asong ulol, asong ulol, asong ulol ng palasyo, asong ulol, asong ulol, asong ulol ng palasyo" [they who guard the throne, trained by foreign soldiers so that they would help keep their masters in power; mad dogs, mad dogs in the palace]. In Anong Klaseng Bayani [What Kind of Hero], Musikang Bayan criticizes the state's cultural apparatus in maneuvering and forming social mind giving consent to the exploitative migrantlabor policy: "di na kami paloloko muli; tigilan na ninyo ang pagkukunwari; natututo na kaming lumaban, natututo na kaming lumaban; migranteng Pilipino ngayo'y lumalaban" [we won't allow you to deceive us again; stop your hypocrisy; we learn how to fight; Filipino migrants (Overseas Filipino Workers) are now fighting back against you]. Such a social condition sprouts from the country's long history of colonial subjugation to the post-colonial unequal treaties with developed countries. "Globalization... imparted on our society... needs to be critiqued", Prof. Jove Jim Aguas (2019) reiterated during the PNPRS national conference on Society, Heritage and Indigenous Arts. ${ }^{18}$ And the reactionary government's counter-revolutionary programs through its ISAs can be countered with "cultural renaissance" through Musikang Bayan's MMPN music. "Draw strength from our identity", said Saint Louis University President Gilbert Sales (2019) on Society, Heritage, and Indigenous Arts. ${ }^{19}$ To this extent, it is fitting to actuate the words of Kidlat Tahimik (2019) in "resisting cultural imperialism."20 Otherwise, "economic emancipation" and "political independence" are nothing but a dream in a liberal democracy that paves way for neoliberal capitalism begetting plunder of the country's natural resources and 
profiteering from colonial culture. But renewing the mode of production needs consciousness to legitimize, support and maintain it (Althusser 1971, 132-133).

...ensure subjection to the ruling ideology (Althusser 1971, 133)... the reciprocal action of the superstructure on the base (135-136)... no class can hold state power over a long period without at the same time exercising its hegemony over and in the State Ideological Apparatuses (146)

As cultural ISA, music operates in other apparatuses, e.g., politics, education, religion, family, media, etc. Gradually, it can instill ideology that suits the role it has to fulfill in class society (Althusser 1971, 154-155), for ideology is manufactured and determined by class struggle (161). In this regard, Gramsci considers the struggle of the basic sector consolidating the strength of the weak to propel struggles (Glassman 2013, 241). In its Patuloy ${ }^{21}$ [Continue], Musikang Bayan elucidates that the people's war will not end if the root causes of social injustice are not addressed.

Hanggat kinakamkam ang lupain at walang makain ang nagtatanim, hanggat kalakal ang paggawa at lumilikha'y sinasamantala, hanggat maralitang komuninad pinapalayas at dinadahas, hanggat dayuhan at iilan ang naghahari sa ating bayan, hanggat walang kalayaan, hanggat walang katarungan, walang tunay na kapayapaan. [Until there's no genuine agrarian reform and farmers go hungry until production is profiteering and the workers are exploited until urban settlers are demolished and harassed until foreigners and the few are ruling in our society until there's no genuine independence until there's no social justice, there's no just and lasting peace]

Music, hence, can help in conscienticizing to counter ISAs. Lessons from educational discussions and/or public fora may be forgotten, but people who enjoy last song syndrome bear the message "in their mouths" and "in their minds." As Musikang Bayan entertains its listeners, it educates; it conscienticizes. Together with the National Democratic Movement, national industrialization with genuine land reform is carrying the aim of making Philippine culture nationalist, scientific and mass-oriented. Organizational work is important in dealing with economic relations vis-à-vis the socio-political (Amin 2014, 11). In the absence of educational discussion and/or public fora, it is convenient to conscienticize through music. In pursuing social transformation, revolutionizing culture is vital to the success of the struggle. Changing the social and political also means influencing the cultural (Elicor 2016, 90-91). Kidlat Tahimik (2019) elucidated on Society, Heritage and Indigenous Arts during the PNPRS national conference. ${ }^{22}$

We're still stuck in the Western echo-chamber. We should be outside of the Hollywood echo-chamber and tell our own stories from our own 
experience. Overdose of Hollywood stories... echo-chamber... maximal profit. The world cannot continue on its track... capitalism for capitalists' sake, consume for consumerism...

Culture is not just commercialized but politicized. In influencing its former colonies, the Global North hegemonizes not only the politico-economic and military affairs but also clutches the culture of the Global South. Against the capitalist ideology, cultural activists work in wielding political power. The significance of cultural work was evident in ousting presidents Marcos and Estrada. Cultural groups produced progressive songs. Bands and theatre guilds performed on a makeshift stage during protest rallies. Recently, with many progressive songs composed, too little is heard, and too little heard them among the hundred-million population. Many are dimly aware of the cultural ISA, but today's technology "democratizes" music and empowers the listeners to choose the genre of songs they want to listen to since mainstream media constrain and repress the MMPN songs that are detrimental to the base-superstructure dynamics. Apolitical art is political. Artistry should have a relationship with the aim of transforming society (Zedong 1967, 75-78). It offers not just a description of society but a certain critique with class analysis. "Cultural renaissance" or "cultural revolution" conscienticizes and unites the people against the feudal, colonial, and bourgeois-idealist culture.

\section{CONCLUSION}

Progressive artists employ MMPN music through popular genres, but their songs are barely promoted by mainstream media playing bourgeois-idealist songs. Through MMPN music with the aid of "democratized" technology, the people can grasp the material condition and can conceive its material solution borne out of clear and critical consciousness orienting culture towards "economic emancipation" and "political independence." Root music back to society's material condition since popular idealist music is dominating. Make music the carrier of "cultural renaissance." But instead of dealing scientifically with the people's problem, the material condition is blurred with bourgeois-idealist lyrics. It instills unscientific and apolitical consciousness.

Moreover, being apolitical is politically wrong and biased with the one holding power and against those who suffer exploitation, oppression, and marginalization by the powerful. Hence, music is never neutral. It has to be rooted in the society's material condition for music without praxis is a blurred consciousness. So instead of just looking for its entertaining and comforting lyrics, the listeners should look for its conscienticizing message. Since it entertains, it should conscienticize the listeners paving the way for them to act about the things that cause social problems. It should be inspired by the material condition to expound a material solution. The artists, then, should be grounded with the people where and/or whom cultural artists compose songs through a particular situation experienced by the basic sectors of the society. In short, music should have a mass line, i.e., an interaction between the artists and the people. Articulators of collective consciousness are how artists should present themselves to 
their listeners. Since the "established order" is legitimized, supported, and maintained by ISAs, like culture, articulate the people's socio-politico-economic consciousness through music. Music plays a vital role in transforming political culture, but music that is not culturally grounded is not politically awake. Through music, the exploited and oppressed may express themselves and form a critical consciousness of the broad alliances of people's organizations. With the MMPN composition of music, the consciousness formed is aware of the material condition and can look for materialist solutions. Hence, inculcate into the consciousness of the people not the capitalist ideology but the critical consciousness borne of the material condition of the exploited and oppressed. The emancipation of the exploited and the oppressed is not viable without revolutionizing culture. Sociologists in and out of the country had long been identifying unhealthy Filipino culture as a deterrent in transforming politics. Popular music is proficient in "corrupting the minds of the youth," but according to Mogoș (2016, 24), "music becomes the perfect vehicle for the construction of a new narrative..." Music, then, is (a)political and should be political. It should collectivize the people's consciousness and give not false hopes but scientific consciousness as a political community describing its material condition. Listening to music is not about forgetting our problems but articulating our consciousness, finding a material solution to our material problems. Challenge the legitimacy of bourgeois social structure, stratification, and relations of production. The "established order" is made possible since social institutions are part of the relations of class domination (Althusser cited by Bidet in his Introduction to On the Reproduction of Capitalism: Ideology and Ideological State Apparatuses; Althusser 2014, xxiv).

If music is apolitical, it is alienating. If it is alienating, it is not mass-oriented; if it is not mass-oriented, it is not emancipatory. Music, then, should be an authentic expression of people's lived experiences, hopes, goals, and the society's material condition; thus, scientific. MMPN music agitates and educates because the massoriented culture of the collective citizens leads to emancipatory politics (Balibar 2002 cited in Dunst \& Edwards 2011, 2-7). Otherwise, it exercises cultural hegemony over the lives of people, as Althusser $(1971,164)$ had said about Marx's Feuerbachian idea: "men make themselves an alienated imaginary representation of the conditions of their existence because these conditions of existence are themselves alienating." Since today's mainstream music in the Philippines is alienated from society's material condition, it should be MMPN promoting mass-oriented culture towards emancipatory politics through the articulation of the collective consciousness of the people.

\section{NOTES}

1. The earlier draft of this paper was presented during the 2019 national conference on Society, Heritage, and Indigenous Arts organized by the Philippine National Philosophical Research Society at Saint Louis University in Baguio City, February 7-9, 2019.

The author is grateful to the referees and the editor for providing enlightening comments and to the lead-vocal-composer of Musikang Bayan, Danny Fabella, for making himself available for the interview shedding light on the content of the albums 
Rosas ng Digma, Walang-Hanggan, Baliktad na ang Mundo, Ilusyon, Igpaw, and his solo Kung Kami'y Manlalaban.

2. The observation is based on the author's lived experience in employing progressive music in teaching philosophy and/or social science courses from 2014 to 2019 among eight schools: three public universities, one Catholic university, one private college, and three public high schools both junior and senior high.

Elicor $(2016,91)$ provides an example of Filipino musicians whom he describes as "militant," and Danny Fabella of Musikang Bayan is one of those artists.

3. Lockard $(1996,156)$ says that militants are those who offer radical criticisms against the "established order." Though it is understandable to have Lockard citing Freddie Aguilar a decade after the demise of the Marcos dictatorship, in this paper, Aguilar can no longer be categorized as such. Lockard $(1996,157,167)$ somehow, at this juncture, lucidly describes the militants as fearless in expressing political dissent and/or resistance.

4. Adorno's argument, in his aesthetic theory, posits music as progressive when it advances the concern of that which is social, political, and/or cultural.

5. It promotes the country's sovereignty and/or independence against neocolonialism (Lockard 1996, 160, 166). Lockard (1996, 164) cites Epifanio San Juan's Towards a People's Literature expounding nationalism vis-à-vis the construction of a "people's culture" against that which is propagated by capitalist ideology.

6. In using the term, Nick Joaquin (1978, 118-119) refers to a culture that is not alienated from the people - that which is not identified with what the former colonial masters tried to instill.

7. It considers the science of history that is dialectical - that which is not essentialist/universalist or postmodernist as exemplified by Derrida and/or Foucault (Fracchia 1991, 154-155).

8. That which is not divorced from the society's material condition is massoriented. It sees the perspective of the people - the society, not the state. Being massoriented is not the same as being popular; it does not reflect the hegemonic power of the "established order."

9. The Philippine Drug Enforcement Agency (PDEA) wanted to ban the song Amatz of rapper Shanti Dope over the allegation that it promotes the use of marijuana

10. The Department of Interior and Local Government (DILG) eyed legal complaints against the teleserye Ang Probinsyano because the former says that the latter depicts the national police negatively.

11. The Manila City Council declared Panday Sining persona non grata due to protest graffiti. Members of the same group were formerly detained because of street art activism.

12. While there is no scholarly written paper that can prove this claim, the author's statement is an expression of his personal lived experience as a volunteer for the Commission on Social Advocacies - COSA, Archdiocese of Cebu.

13. See Paulo Freire's Pedagogy of the Oppressed positing the "seecomprehend-act" method. 
14. Renato Constantino used this term along with "political independence" and "economic emancipation" in his Miseducation of the Filipino.

15. Though the term and/or concept "people's struggle" may mean differently, the author refers to the so-called National Democratic Movement in the Philippines.

16. The author has not retrieved a video of Kidlat's plenary talk, just the conference program from the PNPRS website and the photo album from the PNPRS Facebook page. As much as the author would like to cite well-documented papers published in academic journals, Kidlat's talk is impossible to ignore since the earlier draft of this paper was presented at the conference where Kidlat delivered his plenary talk. The weight, clarity, and relevance of Kidlat's lecture prompted the author to write down notes and integrate them with the paper, confirming the message that the author would like to convey along with the theme of the conference.

17. See Guerrero's discussion on classes in Philippine society in the third chapter of his Philippine Society and Revolution.

18. As the PNPRS Executive Governor, Dr. Aguas delivered this message as part of his Opening Remarks on February 7, 2019, at the Fr. Francis Gevers Hall of Saint Louis University in Baguio City, Philippines.

19. Fr. Sales admonished the participants during his Welcome Message on February 7, 2019, at the Fr. Francis Gevers Hall of Saint Louis University in Baguio City, Philippines.

20. Kidlat Tahimik incited inspiration during the First Plenary Presentation on February 7, 2019, at the Fr. Francis Gevers Hall of Saint Louis University in Baguio City, Philippines.

21. This song was dedicated to the memory of Bishop Alberto Ramento, and was recorded by Musikang Bayan with Fr. Alex Bercasio, CSsR, and was released together with the Album Walang-Hanggan.

22. While the readers of this paper may not retrieve documentation to watch the plenary talk, Kidlat Tahimik is a national artist whose work and ideas are deliberated by some authors in published papers written scholarly.

\section{REFERENCES}

Aguas, Jove Jim. 2019. Opening Remarks during the National Philosophy Conference of the Philippine National Philosophical Research Society at Saint Louis University in Baguio City, Philippines, February 7-9, 2019.

Althusser, Louis. 1971. Lenin and philosophy and other essays. Translated by Ben

Brewster. New York: Monthly Review Press.

Althusser, Louis. 2005. For Marx. Translated by Ben Brewster. London: Verso.

Althusser, Louis. 2006. Philosophy of the encounter: Later writings 1978-87. Edited by François Matheron and Oliver Corpet. London: Verso.

Althusser, Louis. 2014. An invitation to reread Althusser. Introduction by Jacques

Bidet. In On the reproduction of capitalism: Ideology and ideological state apparatuses. Translated by G.M. Goshgarian. London: Verso, xxiv.

Althusser, Louis. 2015. Reading capital (The Complete Edition). Translated by Ben Brewster \& David Fernbach). London: Verso. 
Amin, Samir. 2014. Capitalism in the age of globalization: The management of contemporary society. London: Zed Books Ltd.

Ang, Walter. 2018. Barangay to Broadway: Filipino American theater history. Pennsylvania: Walter Ang.

Balibar, Étienne. 2002. Three concepts of politics: Emancipation, transformation, civility. In Politics and the Other Scene. Translated by C. Jones, J. Swenson and C. Turner. London: Verso.

Constantino, Renato. 1966. Miseducation of the Filipino. Quezon City: Malaya Books.

Cronenberg, Stephanie. 2008. Voices: Reflections on an American icon through words and song. Washington, DC: The Choral Arts Society of Washington.

Dunst, Alexander, and Caroline Edwards. 2011. Collective subjects, emancipatory cultures, and political transformation. Subjectivity 4 (1), 1-8. doi:10.1057/sub.2010.29.

Elicor, Peter Paul. 2016. Music and the culture industry: Theodor Adorno and Gary Granada. Social Ethics Society Journal of Applied Philosophy 2 (1), 79-97.

Fabella, Danny. 2019. Interview by the author (during the Halad Concert on December 6 at the CAP Auditorium in Cebu City).

Fontana, Benedetto. 2013. The concept of nature in Gramsci. In Gramsci, Space, Nature, Politics. Edited by Ekers, Michael, Gillian Hart, Stefan Kipfer, and Alex Loftus. MA, USA: Wiley-Blackwell, 126-138.

Fracchia, Joseph. 1991. Marx's aufhebung of philosophy and the foundations of a materialist science of history. History and Theory. 30 (2), 153-179.

Freire, Paulo. 2000. Pedagogy of the oppressed. 30th-anniversary edition. New York: Continuum.

Giles, Steve, and Tom Kuhn. 2015. Brecht on art and politics. London: Bloomsbury.

Gilmore, Nicholas. 2017. 9 Songs of uprising and revolution. The Saturday Evening Post. Available at https://www.saturdayeveningpost.com/2017/11/9-songsuprising-revolution/. Accessed: January 4, 2020.

Glassman, Jim. 2013. Cracking hegemony: Gramsci and the dialectics of nature. In Gramsci, Space, Nature, Politics. Edited by Ekers, Michael, Gillian Hart, Stefan Kipfer, and Alex Loftus. MA, USA: Wiley-Blackwell, 241-247.

Guerrero, Amado. 1970. Philippine society and revolution. 4th ed. Hong Kong: Ta Kung Pao.

Habermas, Jürgen. 1985. Civil disobedience: Litmus test for the democratic constitutional state. Berkeley Journal of Sociology, 30, 95-116.

Harvey, David. 1996. Justice, nature and the geography of difference. Cambridge, MA: Blackwell.

Horsley, Stephanie. 2015. Facing the music: Pursuing social justice through music education in a neoliberal world. In Oxford Handbook of Social Justice in Music Education. Edited by Cathy Benedict, Patrick Schmidt, Gary Spruce, and Paul Woodford. New York: Oxford University Press.

International Communist Seminar. 2001. Imperialist globalization and the world revolutionary process. Available at 
https://www.bannedthought.net/Philippines/CPP/Rebolusyon/2001/N3-JulSep/R2001-03en.pdf. Accessed: January 4, 2020.

Joaquin, Nick. 1978. The Filipino as English fictionist. Philippine Quarterly of Culture and Society 6 (3), 118-124.

Justice, Jenny. 2019. How to develop your sociological imagination for empathy and social justice. Available at https://medium.com/swlh/how-to-develop-yoursociological-imagination-for-empathy-and-social-justice-2a6068800793.

Accessed: January 4, 2020.

Kipfer, Stefan, and Gillian Hart. 2013. Translating Gramsci in the current conjuncture. In Gramsci, Space, Nature, Politics. Edited by Ekers, Michael, Gillian Hart, Stefan Kipfer, and Alex Loftus. MA, USA: Wiley-Blackwell, 333-335.

Labayen, Julio. 1995. Revolution and the Church of the poor. Quezon City: Claretian. Levy, David. 2011. Review of Steven G. Medema's The Hesitant Hand: Taming selfinterest in the history of economic ideas. Erasmus Journal for Philosophy and Economics 4 (2), 97-104. http://ejpe.org/pdf/4-2-br-5.pdf.

Lockard, Craig. 1996. Popular music and politics in modern Southeast Asia: A comparative analysis. Asian Music 27 (2), 149-199. https://doi.org/10.2307/834493.

Lumbera, Bienvenido. 2019. Review (written on the cover page of the CD case) of the album Kung Kami Manlalaban by Danny Fabella, songwriter and lead vocal of Musikang Bayan.

Mogoș, Petrică. 2016. State-Apparatuses of creative Control: Rock music scenes, youth countercultures and dissent in socialist Romania. Research. Master in the Sociology of Culture, Media, and the Arts. Erasmus School of History, Culture, and Communication, Erasmus University, Rotterdam. Available at https://pdfs.semanticscholar.org/5133/4514f71603353a3311f3ae52f487b3bf82 9f.pdf. Accessed: January 4, 2020.

Morton, Adam David. 2013. Traveling with Gramsci: The spatiality of passive revolution. In Gramsci, Space, Nature, Politics. Edited by Ekers, Michael, Gillian Hart, Stefan Kipfer, and Alex Loftus. MA, USA: Wiley-Blackwell, 5051.

Powell, Bryan, Gareth Dylan Smith, and Abigail D'Amore. 2017. Challenging symbolic violence and hegemony in music education through contemporary pedagogical approaches. Education 3-13, 45: 6, 734-743. https://doi.org/10.1080/03004279.2017.1347129.

Sales, Gilbert. 2019. Welcome Message during the National Philosophy Conference of the Philippine National Philosophical Research Society at Saint Louis University in Baguio City, Philippines, February 7-9, 2019.

Santiago, Jess. 2019. Review (written on the cover page of the CD case) of the album Kung Kami Manlalaban by Danny Fabella, songwriter and lead vocal of Musikang Bayan.

Short, Nicola. 2013. Difference and inequality in world affairs: A Gramscian analysis. In Gramsci, Space, Nature, Politics. Edited by Ekers, Michael, Gillian Hart, Stefan Kipfer, and Alex Loftus. MA, USA: Wiley-Blackwell, 211. 
Taguiwalo, Judy. 2019. Review (written on the cover page of the CD case) of the album Kung Kami Manlalaban by Danny Fabella, songwriter and lead vocal of Musikang Bayan.

Tahimik, Kidlat. 2019. Plenary Talk on Society, Culture and Heritage during the National Philosophy Conference of the Philippine National Philosophical Research Society at Saint Louis University in Baguio City, Philippines, February 7-9, 2019.

Vila, Alixandra Caole. 2018. The 10 best Philippine bands and singers of all time for Independence Day. South China Morning Post. Available at https://www.scmp.com/culture/music/article/2150229/10-best-philippinebands-and-singers-all-time-independence-day. Accessed: January 4, 2020.

Wainwright, Joel. 2013. On the nature of Gramsci's conception of the world. In Gramsci, Space, Nature, Politics. Edited by Ekers, Michael, Gillian Hart, Stefan Kipfer, and Alex Loftus. MA, USA: Wiley-Blackwell.

Zedong, Mao. 1967. Talks at the Yenan Forum on literature and art. In Selected Works of Mao Tse-tung, 3, Foreign Languages Press, Peking, 69-98. 